\title{
GENERALIZED DOWLING DEGOS DISEASE: A CASE REPORT
}

\author{
P. Anila Sunandini ${ }^{1}$, C. Subhasini ${ }^{2}$, T. S. Mohan Rao ${ }^{3}$, K. Venkata Chalam4, B. Durga Bhavani ${ }^{5}$
}

\section{HOW TO CITE THIS ARTICLE:}

P. Anila Sunandini, C. Subhasini, T. S. Mohan Rao, K. Venkata Chalam, B. Durga Bhavani. "Generalized Dowling Degos Disease: A Case Report". Journal of Evolution of Medical and Dental Sciences 2015; Vol. 4, Issue 17, February 26; Page: 2971-2974, DOI: 10.14260/jemds/2015/428

ABSTRACT: Dowling-Degos disease (DDD) is a rare autosomal dominant disease characterized by numerous, symmetrical, progressive pigmented macules over the axillae, groins, face, neck, arms and trunk as well as scattered comedo-like lesions (dark dot, follicles) and pitted acneiform scars. Histopathology is diagnostic testing using a distinctive form of acanthosis, characterized by an irregular elongation of thin branching rete ridges, with a concentration of melanin at the tips. We report a case of generalized DDD with reticulate hyperpigmentation, scattered comedo like lesions and pitted acneiform scars in a 35 year old female patient.

KEYWORDS: Dowling-Degos disease, Pigmentary disorder, Reticulate.

INTRODUCTION: Dowling-Degos disease (DDD) is a rare autosomal dominant reticulate pigmentary disorder. It was first established by Wilson-Jones and Grice,(1) though it was described as early as 1938. Few reports have appeared in the Indian literature.(2,3,4) It is characterized by numerous, symmetrical, progressive and pigmented macules over the axillae, groins, face, neck, arms and trunk as well as scattered comedo-like lesions (dark dot follicles) and pitted acneiform scars.(5,6) The disorder usually appears and/or worsens after puberty.

Histopathology is diagnostic testing using a distinctive form of acanthosis, characterized by an irregular elongation of thin branching rete ridges, with a concentration of melanin at the tips. $(7,8)$ Recently, the loss-of-function in the keratin 5 (KRT5) gene and a gene locus mapping to chromosome 17 p13.3 have been described in cases of DDD.(9,10) Here we report a case with autosomal dominant inheritance of a skin disorder with clinical features of generalized DDD.

CASE REPORT: A 35-year-old woman presented with reticulate hyperpigmented skin lesions over the face, chest, back, axillae and flexures since 5 years. Initially, the lesions first started over the face as small hyperpigmented macules. Then she developed similar lesions over the back, neck, axilla, inguinal region, infra mammary, chest and extremities over the next year. Gradually, these lesions progressed to form pits filled with blackish material. There was no history of inflammatory skin diseases prior to the onset of the lesion.

There was no significant past medical, surgical and gynecological history.

The patient was born of a non-consanguineous marriage. History of similar lesions was present in her mother, brother.

Her general physical examination was normal.

Dermatological examination revealed a symmetrical reticulate hyperpigmentation predominantly affecting the face, neck, axilla, groin, Inframammary region, forearm, back and legs. Multiple pits varying in size from 1 3 mm and open comedone-like lesions were distributed over the cheeks, periorbital area, forehead and neck. Symmetrically distributed reticulate hypopigmentation was also seen in the hands, legs and chest. 


\section{CASE REPORT}

The mucosa, nails, teeth and hair were normal.

On investigation, complete blood count, blood chemistry, liver and renal function tests were all within normal limits.

A biopsy was conducted from a hyperpigmented lesion over the shin, and histopathological examination revealed hyperkeratosis, acanthosis and irregular elongated thin branching rete ridges growing down into the dermis and increased melanin pigment in the lower part of the rete pegs.

These features were entirely consistent with the clinical diagnosis of DDD.

DISCUSSION: Dowling-Degos disease (DDD) is a rare autosomal dominant reticulate pigmentary disorder. It was first established by Wilson-Jones and Grice,(1) though it was described as early as 1938. Few reports have appeared in the Indian literature. $(2,3,4)$

DDD has characteristics of clinical and histopathological features. The diagnosis is very simple when classical features are present, as observed in our case.

In our case, the patient had generalized DDD. The patient had the typical features of classic DDD (reticulate hyperpigmentation at flexural area) and generalized reticulate hyperpigmentation on the face, axilla, inframammary area, trunk, limbs and other cutaneous findings, including reticulate hypopigmented macules, facial pits, comedo-like papules.

Histories of similar lesions were present in her mother and brother.

Histopathology is diagnostic with a distinctive form of acanthosis, characterized by downward elongations of thin rete ridges with reticulated or fenestrated patterns, with concentration of melanin at the tips and occasional follicular plugging and horn cysts. ${ }^{7,8)}$

Clinical and histopathological features in our case distinguish this case from other reticulate pigmentary disorders.

The genetic defect of DDD has not yet been well defined. A recently reported series described the loss of-function mutations in the KRT5 gene( ${ }^{(9,10)}$ These data confirm that haplo in sufficiency for K5 engenders an excess of unpaired, soluble K14 that is then responsible for DDD and points to a prominent role for the keratin intermediate filament cytoskeleton within the basal keratinocytes in epidermal pigment biology.(11,12,13) Another genetic defect of DDD has been reported in the gene locus mapping to chromosome 17p13.3 and chromosome 1q21 with pathogenic mutations located in the DSRAD gene.(10)

Genetic studies were not performed in our patient as the patient was not co-operative.

In conclusion, we report a case of generalized DDD with autosomal dominant penetrance for its rarity, as very few cases have been reported from India. $(2,3,4)$

\section{REFERENCES:}

1. Wilson-Jones E, Grice K. Reticulate pigmented anomaly of the flexures. Arch Dermatol 1978; 114: 1150-7.

2. Kumar AS, Pandhi RK, Jacob M, Singh MK. Dowling-Degos disease. Ind J Dermatol Venereol Leprol 1986, 52: 48-9.

3. Mohan L, Bhatia PS, Mishra R, Singh KK, Mukhija RD, Chandra S. Dowling-Degos disease. Ind J Dermatol Venereol Leprol 1991; 57: 251.

4. Udagani MM, Shankar R. Dowling-Degos disease. Ind J Dermatol Venereol Leprol 1994; 58: 139. 


\section{CASE REPORT}

5. Crovato F, Nazzari G, Rebora A. Dowling-Degos disease (reticulate pigmented anomaly of the flexures) is an autosomal dominant condition. Br J Dermatol. 1983; 108: 473-476. [PubMed].

6. Kim YC, Davis MD, Schanbacher CF, Su WP. Dowling-Degos disease (reticulate pigmented anomaly of the flexures): a clinical and histopathologic study of 6 cases. J Am Acad Dermatol. 1999; 40: 462-467. [PubMed].

7. Harper JI, Trembath RC. Genetics and genodermatoses. In: Rook AJ, Burns T, editors. Rook's textbook of dermatology. 7th ed. Malden, Mass: Blackwell Science; 2004. pp. 15.11-15.13.

8. Howell JB, Freeman RG. Reticular pigmented anomaly of the flexures. Arch Dermatol. 1978; 114: 400-403. [PubMed].

9. Betz RC, Planko L, Eigelshoven S, Hanneken S, Pasternack SM, Bussow H, et al. Loss-of-function mutations in the keratin 5 gene lead to Dowling-Degos disease. Am J Hum Genet. 2006; 78: 510519. [PMC free article] [PubMed].

10. Li CR, Xing QH, Li M, Qin W, Yue XZ, Zhang XJ, et al. A gene locus responsible for reticulate pigmented anomaly of the flexures maps to chromosome 17p13.3. J Invest Dermatol. 2006; 126: 1297-1301. [PubMed].

11. Bonifas JM, Rothman AL, Epstein EH., Jr Epidermolysis bullosa simplex: evidence in two families for keratin gene abnormalities. Science. 1991; 254: 1202-1205. [PubMed].

12. Bonifas JM, Bare JW, Lynch ED, Lebo RV, Epstein EH., Jr Regional assignment of the human keratin 5 (KRT5) gene to chromosome 12q near D12S14 by PCR analysis of somatic cell hybrids and multicolor in situ hybridization. Genomics. 1992; 13: 452-454. [PubMed].

13. Stephens K, Ehrlich P, Weaver M, Le R, Spencer A, Sybert VP. Primers for exon-specific amplification of the KRT5 gene.

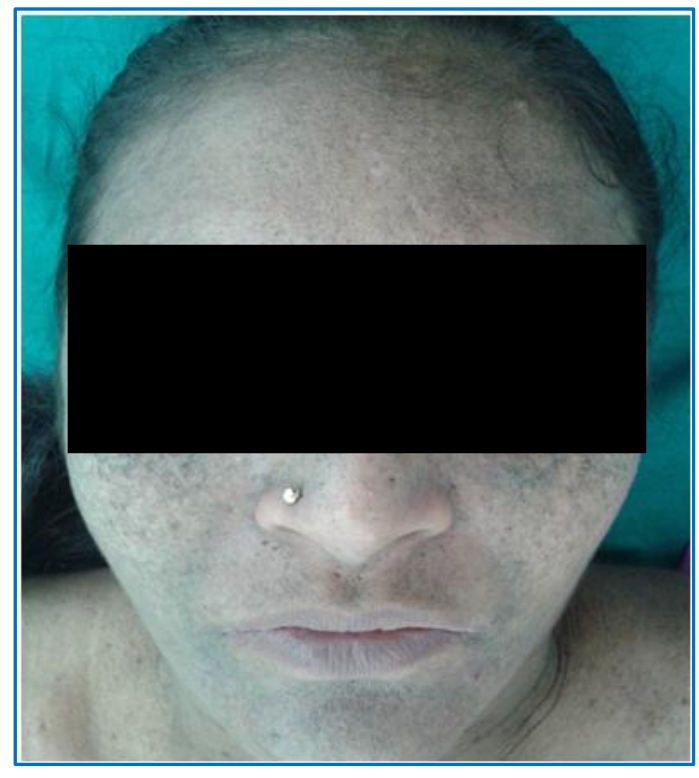

Fig. 1

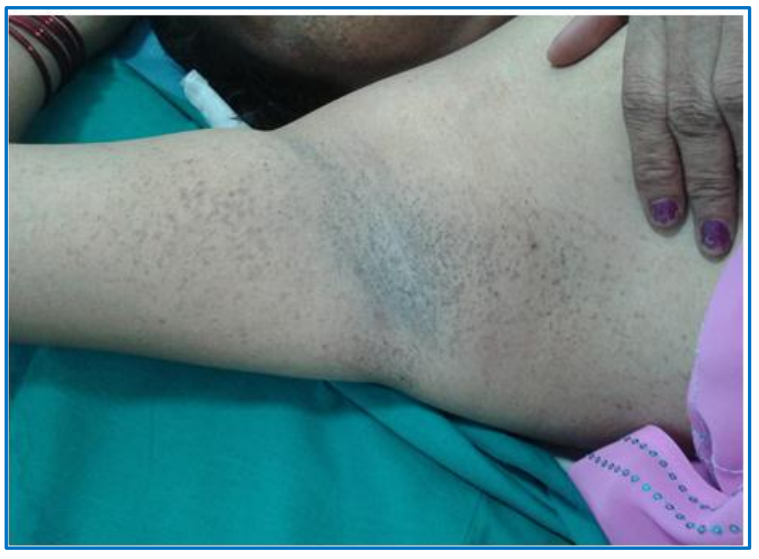

Fig. 2 


\section{CASE REPORT}

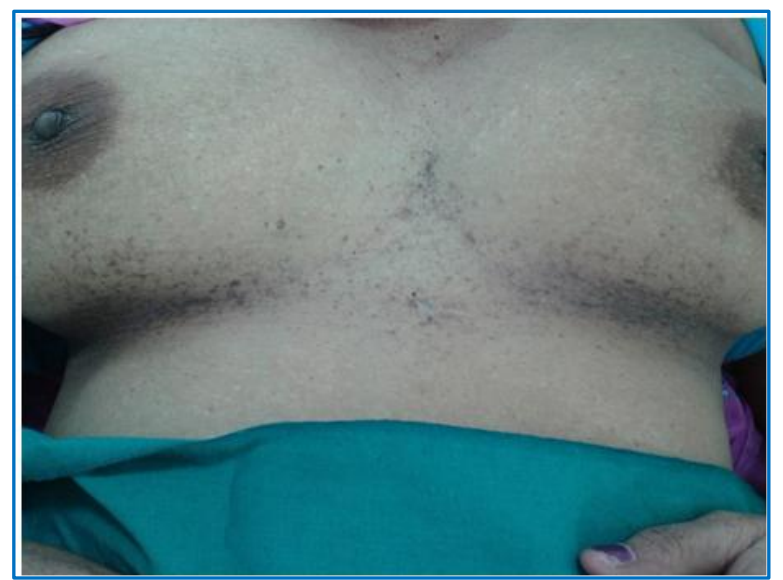

Fig. 3

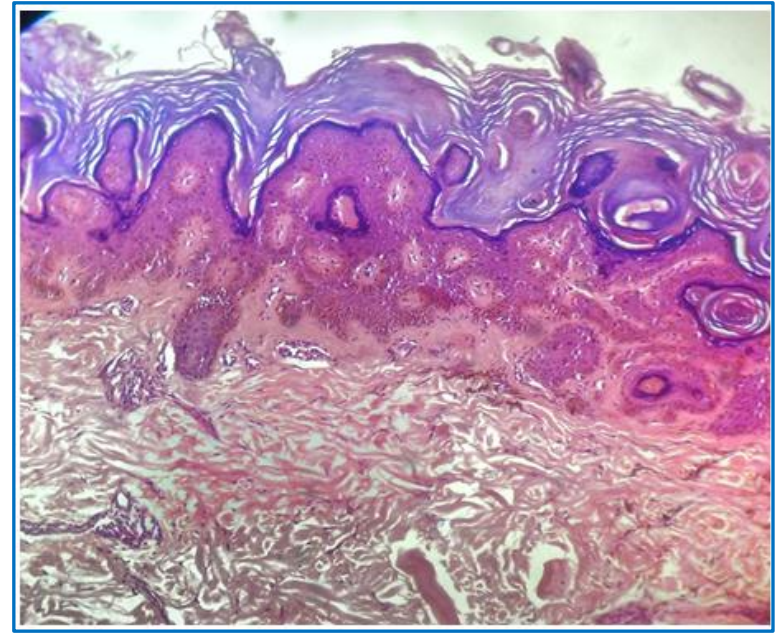

Fig. 4: Skin biopsy - histopathology

\section{AUTHORS: \\ 1. P. Anila Sunandini \\ 2. C. Subhasini \\ 3. T. S. Mohan Rao \\ 4. K. Venkata Chalam \\ 5. B. Durga Bhavani}

\section{PARTICULARS OF CONTRIBUTORS:}

1. Professor, Department of Dermatology, Andhra Medical College, Vizag.

2. Assistant Professor, Department of DVL, Andhra Medical College, Vizag.

3. Assistant Professor, Department of Dermatology, Andhra Medical College, Vizag.

\section{FINANCIAL OR OTHER}

COMPETING INTERESTS: None
4. Assistant Professor, Department of Dermatology, Andhra Medical College, Vizag.

5. Junior resident, Department of DVL, Andhra Medical College, Vizag.

\section{NAME ADDRESS EMAIL ID OF THE CORRESPONDING AUTHOR:}

Dr. P. Anila Sunandini,

Professor, Department of DVL, Andhra Medical College, Vizag. E-mail: gppatnala@yahoo.co.in

Date of Submission: 07/01/2015. Date of Peer Review: 08/01/2015. Date of Acceptance: 17/01/2015.

Date of Publishing: 25/02/2015. 